\title{
Correlation between Leukocyte Numbers and Body Size of Rainbow Trout
}

\author{
Rzgar M. Jaafar*, Maki Ohtani, Per W. Kania, Kurt Buchmann \\ Department of Veterinary Disease Biology, Faculty of Health and Medical Sciences, University of Copenhagen, \\ Frederiksberg, Denmark \\ Email: *rezgarhadad@sund.ku.dk
}

Received 15 August 2016; accepted 10 September 2016; published 13 September 2016

Copyright (C) 2016 by authors and Scientific Research Publishing Inc.

This work is licensed under the Creative Commons Attribution International License (CC BY). http://creativecommons.org/licenses/by/4.0/

(c) (i) Open Access

\begin{abstract}
Immune cells in rainbow trout Oncorhynchus mykiss comprise granulocytes (neutrophils, basophils and eosinophils), macrophages/monocytes and lymphocytes (B- and T-cells). These cellular elements occur early during the ontogenetic development of trout and allow both innate and adaptive responses towards an antigen to be initiated even in fry. The number of leukocytes in individual fish at different developmental stages is likely to influence the capacity of the fish to respond simultaneously to several antigens (pathogens and vaccine components). This parameter may therefore be crucial for both wild and cultured fish and we show that the size of the leukocyte population increases exponentially with body size of rainbow trout. Four groups (5 fish/group) of naive rainbow trout (Oncorhynchus mykiss) with a mean body weight of 2 - $4 \mathrm{~g}$ (group I), 4 - 6 g (group II), 25 - 30 g (group III), and 650 - 780 g (group IV) were investigated. The number of lymphocytes was generally higher in head kidney compared to blood and spleen but they dominated in all samples (blood, head kidney and spleen) and their numbers increased exponentially with fish size. Percentages of lymphocytes in relation to neutrophils and macrophages were higher in spleen (98\% - 99\%) compared to blood and head kidney in all groups. Fish fry is therefore equipped to respond specifically against one or a few vaccine antigens, but the capacity to raise protective responses against a repertoire of pathogens may be limited until the larger fingerling stage has been reached. The implications for vaccination of early fry are discussed.
\end{abstract}

\section{Keywords}

Macrophages, Neutrophils, Lymphocytes, Leukocytes, Rainbow Trout

\footnotetext{
${ }^{*}$ Corresponding author.
}

How to cite this paper: Jaafar, R.M., Ohtani, M., Kania, P.W. and Buchmann, K. (2016) Correlation between Leukocyte Numbers and Body Size of Rainbow Trout. Open Journal of Immunology, 6, 101-110. 


\section{Introduction}

The ontogenetic development of immune cells and organs in fish provides the ability of even fry to respond to pathogens [1]-[4]. Central lymphoid organs comprising thymus, kidney (pro-and mesonephros) and spleen are developed sequentially in salmonids [5] [6] and the haematopoitic tissue in kidney is present in these fishes producing erythrocytes and granulocytes before hatching [7]. Yolksac larvae seem to rely on mostly innate responses, but fry of around 0.5 to $0.7 \mathrm{~g}$ activates a series of adaptive elements when responding to pathogen exposure [1]-[3]. Commercial vaccines are generally applied when the fish reaches at least $5 \mathrm{~g}$ body weight (immersion vaccines) [8] or even later (injection vaccines) [9], but recent trends aim at vaccination at earlier time points [10] [11]. The immune system in fish is composed of innate and adaptive elements, and both systems comprise cellular and humoral factors involved in protection against pathogens [12]. Leukocytes including granulocytes (neutrophils, basophils and eosinophils), macrophages/monocytes, lymphocytes (B- and T-cells) are the main players of the cell-mediated immune responses [13] [14] and their role in the early onset of immunity in rainbow trout (Oncorhynchus mykiss) has been treated in a series of papers [1] [2] [5] [6] [15] [16]. Rainbow trout eggs exhibit low expression of several immune genes (IgM, IgT, MHCII, C3, CD4, CD8, TCR and SAA), but expression increases significantly during and after hatching concomitant with the appearance of effector molecules (MHCII, IgT, CD8 and SAA) in tissues of the fish fry [1] [2] [5] [6] [15] [16]. Rainbow trout IgM positive cells may occur as early as 8 days before hatch [16] but become more prevalent $4-5$ days after hatching [15]. During subsequent growth and development of the fish, the number of leukocytes may increase as indicated by studies where immune cells are harvested for in vitro purposes [17] [18]. However, a precise enumeration of leukocyte populations in rainbow trout during its development from fry to adult is not available. The present study, based on microscopical techniques for differential leukocyte counts, describes the number of different leukocyte types including lymphocytes in peripheral blood and central immune organs (head kidney and spleen) in rainbow trout during its development from fry to market size fish.

\section{Materials and Methods}

\subsection{Fish}

Rainbow trout were reared at the Bornholm Salmon Hatchery, Nexø, Denmark, which is a pathogen free recirculated rearing facility supplied with municipal freshwater (see details for securing pathogen free status in Xueqin et al. [19]). Fish were hatched $\left(\right.$ at $\left.77^{\circ} \mathrm{C}\right)$ from disinfected eyed eggs originating from Fousing Trout Farm (Jutland, Denmark). Fish were kept $\left(12^{\circ} \mathrm{C}-13^{\circ} \mathrm{C}\right)$ on a restricted diet $(1.0 \%$ biomass per day) (pelleted trout feed, Biomar, Brande, Denmark). When reaching a mean body weight of $2-4 \mathrm{~g}, 4-6 \mathrm{~g}, 25-30 \mathrm{~g}$, and $650-780 \mathrm{~g}$ fish were transported to the fish keeping facility at the University of Copenhagen (Frederiksberg, Denmark) for acclimatization and sampling in a thermostat controlled fish tank room at $15^{\circ} \mathrm{C}$. At arrival the pathogen free status of fish was confirmed by examining two fish from each group by standard bacteriological and parasitological examination [20].

\subsection{Sampling}

Fish were euthanized by an overdose $(300 \mathrm{mg} / \mathrm{L})$ of MS-222 (Tricaine methane sulphonate, Sigma-Aldrich, Denmark). Blood, head kidney and spleen were sampled from 5 fish per group of the different fish size classes. Weight data for spleen and head kidney were recorded and organs kept in L-15 medium on ice until use. Blood samples from the caudal vessel were collected from small fish by using heparinized 10, 25 and $50 \mu \mathrm{L}$ micropipettes (Hirschmann ${ }^{\circledR}$; Laborgerate, Germany) and from larger fish by heparinized syringes. Blood samples were kept on ice until use.

\subsection{Preparation of Leukocytes}

Leukocytes were collected from blood, head kidney and spleen. Blood was transferred into a tube containing 10 $\mathrm{ml}$ of L-15 medium (\#11415049, Life Technologies, Denmark) with $2.5 \%$ fetal bovine serum (\#10082139, Life technologies, Denmark), heparin (10 U/ml, \#Vnr585679, LEO Pharma, Denmark), penicillin (100 U/ml) and streptomycin $(100 \mu \mathrm{g} / \mathrm{ml})$ (\#15240062, Life Technologies, Denmark). A known amount of head kidney and spleen tissue from each fish was placed in a Petri dish containing $5 \mathrm{ml}$ of L-15 medium. Head kidney and spleen 
cell suspensions were obtained by gently forcing the small pieces of tissue, using a syringe plunger, through a $100 \mu \mathrm{m}$ cell strainer into cold wash medium. The cell suspensions were centrifuged $\left(400 \times \mathrm{g}\right.$ for $10 \mathrm{~min}$ at $4^{\circ} \mathrm{C}$ ), the supernatant discarded and a known volume of medium added to the cell pellet. Then $1 \mathrm{ml}$ of the cell suspension from each sample was individually transferred into a new tube for first counting (named before Percoll treatment). Peripheral blood leukocytes (PBL), head kidney leukocytes (HKL), and spleen leukocytes (SPL) were isolated by centrifugation on a 51\% Percoll (\#P1644-1L, Sigma-Aldrich, Denmark) /PBS gradient. A volume of $3 \mathrm{ml}$ Percoll was gently overlaid by the cell suspension and centrifuged $30 \mathrm{~min}$ at $400 \times g$ at $4{ }^{\circ} \mathrm{C}$. The leukocytes including lymphocyte layer was collected and washed twice with L-15 medium (400× $g$ for 10 min at $4^{\circ} \mathrm{C}$ ). Cell viability was determined with the trypan blue exclusion by using FastRead $102^{\mathrm{TM}}$ disposable plastic counting slides (\#13P1025021, Immune system, UK).

\subsection{Cytospin Preparation}

Cytospin slides were prepared by centrifugation $\left(400 \times g\right.$ for $5 \mathrm{~min}$ at $\left.4^{\circ} \mathrm{C}\right)$ of $100 \mu 1$ of the leukocyte suspension $\left(1 \times 10^{5} \mathrm{cells} / \mathrm{ml}\right)$ at $500 \mathrm{rpm}$, medium acceleration for $5 \mathrm{~min}$, using a Shandon Cytospin 3 cytocentrifuge (Shandon Scientific Ltd, Runcorn, UK). The cytospin slides were subsequently air dried for 3 min by using a hair dryer machine.

\subsection{Cell Staining and Counting (Microscopy)}

Cytospin slides were fixed in $99 \%$ methanol for $1 \mathrm{~min}$ at room temperature, stained with Mayer's hematoxylin (DAKO, Denmark) for 6 minutes, rinsed under running tap water for 10 minutes and dehydrated in series of graded ethanol $(70 \%, 96 \% \times 2$ and $99.9 \%$ and xylene $\times 2)(1$ minute for each step). The slides were mounted in mounting medium DPX (Sigma, Denmark) and read in a compound microscope (Leica DM5000B, Leica Microsystems, Denmark). Cells were counted in three randomly selected zones (visual field $0.19625 \mathrm{~mm}^{2}$ ) from each fish and the total number of cells in a volume of $100 \mu \mathrm{l}$ cell suspension was calculated. The total number of cells in the individual fish was then calculated. The cell populations in the total blood volume of the individual fish were estimated based on the assumption that the blood volume in the organism corresponds to $3 \%$ of the fish body weight [21].

\subsection{Microscopy and Image Processing}

Cytospin slides were examined by bright-field using a compound microscope (Leica DM5000B, Leica Microsystems, Denmark) and digital images created using a Leica MC170 HD camera, Germany. For differential interference contrast microscopy and fluorescence microscopy, the slides were examined with a Fluorescence microscope (Leica DMRHC, Leica Microsystems, Denmark) with a polarisator and analysator filter. The filter A was applied for DAPI (a blue fluorescent DNA stain); the excitation light filter was BP 340 - $380 \mathrm{~nm}$ with beam splitting $400 \mathrm{~nm}$, and a barrier filter LP $425 \mathrm{~nm}$.

\subsection{Statistical Analysis}

Sigma Stat version 11 (USA) was used for conducting normality test (Shapiro-Wilk) for evaluation of the normal distribution of data within each group. The software GraphPad Prism 4 was used for creating graphs and other statistical analysis. Parametric data were tested using Student's $t$-test and one way ANOVA with Tukey's post hoc test. For nonparametric data the Mann-Whitney $U$ test and Kruskal-Wallis one-way ANOVA were performed with the Dunn multiple-comparison test to compare quantitative data. Groups were considered significantly different when $\mathrm{P}<0.05$. Exponential correlation between fish size and cell populations was established by regression analysis using the exponential growth equation method.

\section{Results}

The microscopical analysis showed that heterogeneous cell populations occurred in blood, head kidney and spleen. Monocytes/macrophages (m), neutrophils (n), lymphocytes (l), thrombocytes ( $t$ ), erythrocytes (e), blast cells (b) were characterized by nuclear morphology and presence of granules in cytoplasm (Figure 1(A), Figure 1(C) and Figure 1(F)). The total number of different leukocytes in an individual fish (neutrophil-like cells, 


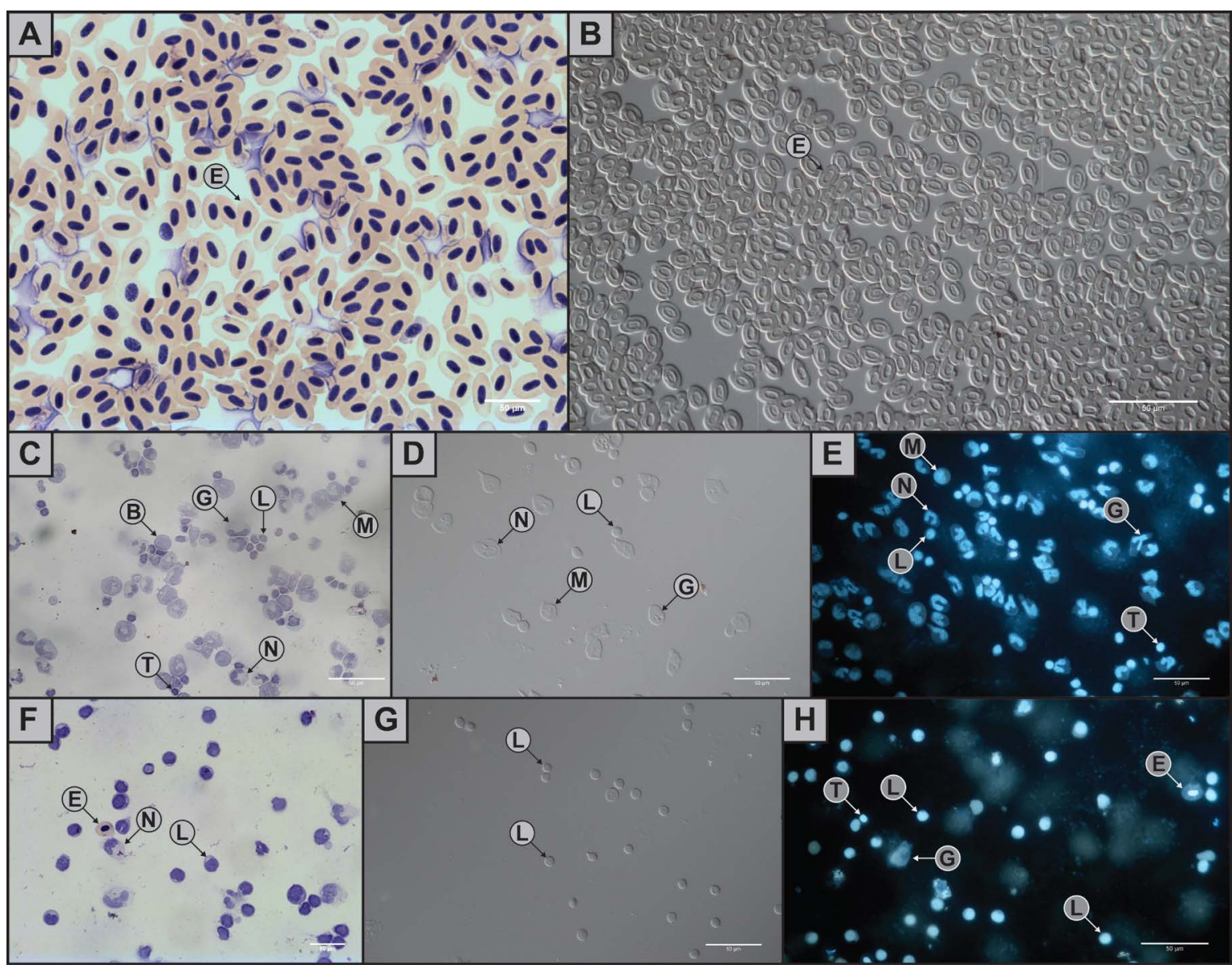

Figure 1. Light microscopy of Percoll non-treated cell populations isolated from whole blood (A and B), head kidney (C-E) and spleen (F-H). (A, C and F) bright field images stained with Mayer's hematoxylin. (B, D and G) differential interference contrast pictures. (E and $\mathrm{H}$ ) fluorescence microscopy pictures stained with DAPI. All pictures are captured by a Leica MC170 HD camera under 40× objective. Scale bars indicate $50 \mu \mathrm{m}$. Erythrocytes (E), Blast cells (B), Granulocyte (G), Monocytes/Macrophages (M), Neutrophils (N), Lymphocytes (L), Thrombocytes (T) were shown with arrows.

monocyte/macrophage-like cells, and lymphocyte-like cells) in whole blood and organs (head kidney and spleen) was estimated for each fish by this method. Total cell counts from five rainbow trout in a given size group were presented and the percentages of different leukocyte types calculated. The total cell counts were estimated before and after Percoll treatment for both head kidney and spleen (Table 1, Supplementary Table 1). With regard to blood the cell counts were obtained after Percoll treatment only due to the confounding effect of numerous erythrocytes present before Percoll treatment (Figure 1(A) and Figure 1(B)). Lymphocytes dominated in all samples (blood, head kidney, and spleen) and their numbers were significantly correlated to fish size (Figure 2). The number of lymphocytes was significantly higher in head kidney compared to blood and spleen in all groups except of group I (Supplementary Table 2). Mean percentages of lymphocytes in relation to neutrophils and macrophages were higher in spleen (98\% - 99\%) compared to blood and head kidney in all groups (Table 1). Neutrophil-like cell rates were more or less similar in blood and head kidney of group I, II, and III. The number of neutrophils and macrophages in head kidney and spleen was correlated to fish size (Supplementary Table 1). Occurrence of neutrophils and macrophages in head kidney was significantly higher compared to blood and spleen in both group I and IV (Supplementary Table 2). The mean percentages of these cells in relation to all three types of cells were higher in blood and head kidney compared to spleen (Table 1).

\section{Discussion}

The size of the leukocyte population increases exponentially with fish size as based on this enumeration of cells 
Table 1. Mean number with standard error (SEM) and mean percentages of different leukocyte populations (macrophage, neutrophil and lymphocyte like-cells) isolated from blood, head kidney and spleen before Percoll treatment determined by light microscopy. Mean number represent 5 rainbow trout per group. Mean percentage in relation to all three types of cells.

\begin{tabular}{|c|c|c|c|c|c|c|}
\hline \multirow[t]{2}{*}{ Groups } & \multicolumn{2}{|c|}{ Macrophages } & \multicolumn{2}{|c|}{ Neutrophils } & \multicolumn{2}{|c|}{ Lymphocytes } \\
\hline & Mean \pm SEM & $\%$ & Mean \pm SEM & $\%$ & Mean \pm SEM & $\%$ \\
\hline \multicolumn{7}{|l|}{ I: 2 - $4 \mathrm{~g}$} \\
\hline Head kidney & $4 \times 10^{3} \pm 1 \times 10^{3}$ & $4 \%$ & $1 \times 10^{4} \pm 4 \times 10^{3}$ & $10 \%$ & $7 \times 10^{4} \pm 2 \times 10^{4}$ & $86 \%$ \\
\hline Spleen & $5 \times 10^{2} \pm 5 \times 10^{2}$ & $1 \%$ & $1 \times 10^{3} \pm 6 \times 10^{2}$ & $2 \%$ & $5 \times 10^{4} \pm 2 \times 10^{4}$ & $98 \%$ \\
\hline \multicolumn{7}{|l|}{ II: 4 - 6 g } \\
\hline Head kidney & $2 \times 10^{4} \pm 9 \times 10^{3}$ & $5 \%$ & $1 \times 10^{4} \pm 7 \times 10^{3}$ & $5 \%$ & $4 \times 10^{5} \pm 1 \times 10^{5}$ & $90 \%$ \\
\hline Spleen & $2 \times 10^{3} \pm 2 \times 10^{3}$ & $1 \%$ & 0 & $0 \%$ & $2 \times 10^{5} \pm 7 \times 10^{4}$ & $99 \%$ \\
\hline \multicolumn{7}{|l|}{ III: 25 - $30 \mathrm{~g}$} \\
\hline Head kidney & $2 \times 10^{4} \pm 9 \times 10^{3}$ & $2 \%$ & 0 & $0 \%$ & $1 \times 10^{6} \pm 2 \times 10^{5}$ & $98 \%$ \\
\hline Spleen & $2 \times 10^{2} \pm 2 \times 10^{2}$ & $0 \%$ & 0 & $0 \%$ & $4 \times 10^{5} \pm 1 \times 10^{5}$ & $100 \%$ \\
\hline \multicolumn{7}{|l|}{ IV: 650 - $780 \mathrm{~g}$} \\
\hline Head kidney & $1 \times 10^{6} \pm 4 \times 10^{5}$ & $7 \%$ & $5 \times 10^{5} \pm 2 \times 10^{5}$ & $5 \%$ & $1 \times 10^{7} \pm 2 \times 10^{6}$ & $88 \%$ \\
\hline Spleen & $3 \times 10^{4} \pm 2 \times 10^{4}$ & $1 \%$ & $3 \times 10^{4} \pm 2 \times 10^{4}$ & $1 \%$ & $5 \times 10^{6} \pm 9 \times 10^{5}$ & $98 \%$ \\
\hline
\end{tabular}

in peripheral blood, head kidney and spleen. This will reflect that larger fish has the potential to respond-both by innate and adaptive responses - to a higher number of antigens than smaller fish. During the ontogenetic development of trout a series of physiological factors change [1] [2] and the total cell number seems to follow this process. The volume of trout also increases significantly with body length and the present data do therefore not shown a higher cell density in larger fish. The rainbow trout used for this experiment were all taken from the same pathogen-free facility and it cannot be excluded that fish from other facilities-facing other temperature regimens and infective status-may differ slightly from the present results. It was seen that the total number of leukocytes was higher in head kidney compared to spleen and blood at all size stages. This has previously been observed in Atlantic salmon (Salmo salar L.) where $\operatorname{IgM}^{+}$cells were more predominant in head kidney than spleen [22] [23] and will emphasize the general and important role of the kidney as a central immune organ. The investigated fish in the present work were non-immunized naïve fish and our data represent a baseline. However, differential involvement of different immune organs and modifications of the leukocyte population may result from infection or stress and it is known that expression of immune related genes and cellular reactions may more prominent in spleen and liver compared to head kidney following vaccination or infection of rainbow trout [9] [24]. The calculated total leukocyte numbers including the lymphocytes in the present work are estimations and may be influenced by various factors. Blood leukocytes were collected and evaluated from the primary vascular system (blood circulation). It is known that the vascular system in fish is divided into two systems, the primary and the secondary vascular system [25]. The latter compartment may have a higher density of putative $\mathrm{CD}^{+} \mathrm{T}^{+}$cells and $\operatorname{IgT}^{+} \mathrm{B}$ cells compared to the former [26]. Furthermore, the number of lymphocytes in an organism possessing an adaptive immune response, such as the rainbow trout, will be a limiting factor for the maximum number of lymphocyte clones the animal can establish and thereby also a limit for the number of antigen reactivities to be raised. In the present work, the total number of lymphocytes (blood, head kidney and spleen) in group I, II, III, and IV, respectively was $4 \times 10^{4}, 4 \times 10^{5}, 6 \times 10^{5}$, and $6 \times 10^{6}$. However, it should be noted that other organs, including thymus, gills, gastrointestinal tract, liver and skin, may contribute to the total pool of lymphocytes in the individual fish-with a number of potential lymphocyte clones [24] [27]-[30] as well. Therefore, the presented counts in this work should be regarded minimum values and future studies should investigate the relative occurrence of cells in different organs. A part of these clones are believed to give rise to memory cells as it has been shown that rainbow trout develops specific immunity, as characterized by antigen specificity and immunological memory [9] [24] [31] [32]. It is hypothesized that fish memory cells are longlived lymphocytes persisting after infection or vaccination [33] [34] and future work should estimate population sizes of memory cells which may be important knowledge for developing vaccination strategies for fish at different ages. In this context, it should be noted that the immune capacity of a fish to react against different anti- 

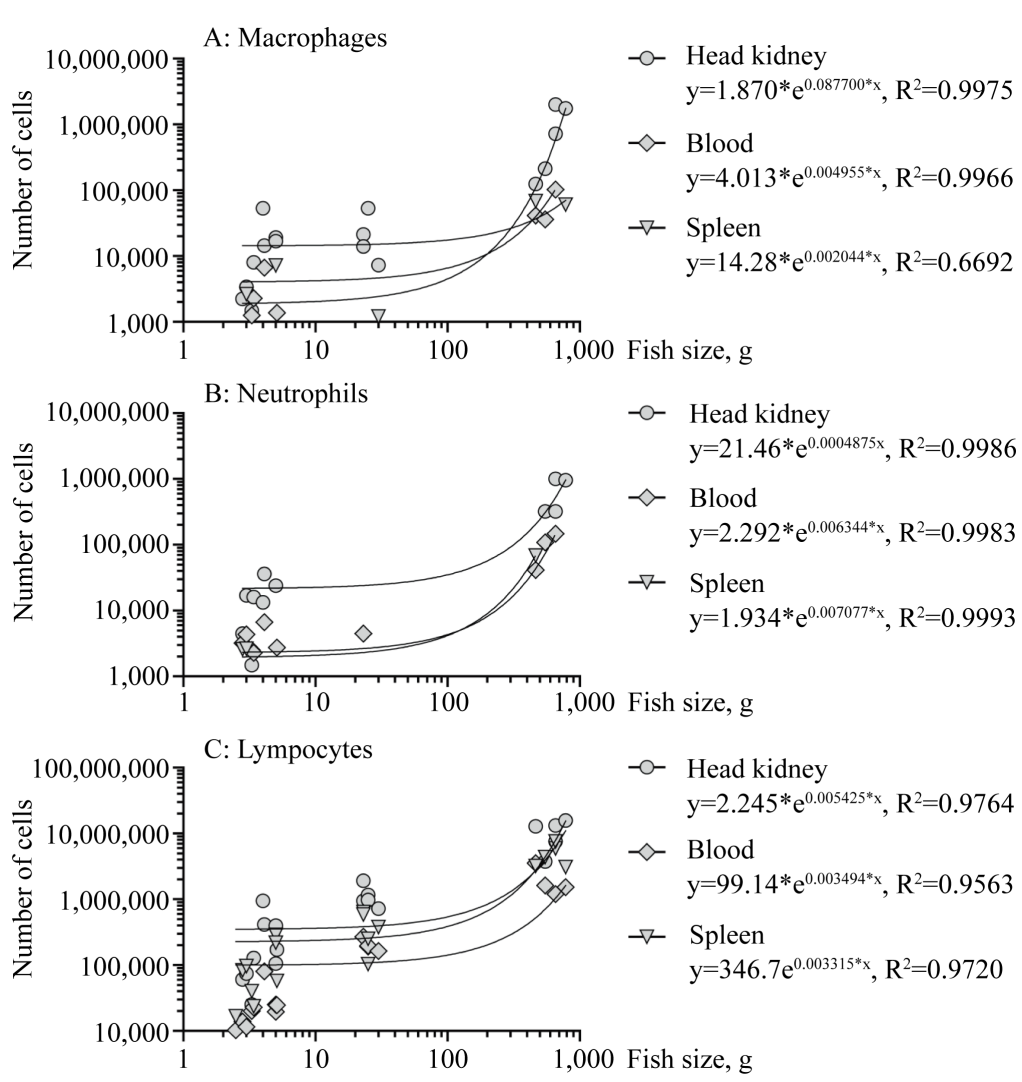

\begin{abstract}
Figure 2. Leukocyte distribution and fish size. The number of macrophage, neutrophil and lymphocyte like-cells in head kidney, blood and spleen determined by light microscopy of cytospin preparations. Regression analysis towards exponential growth curves showed significant correlation between fish size and the cell population size in all cases except of macrophage like-cells in spleen. The squared regression coefficient is indicated as $\mathrm{R}^{2}$.
\end{abstract}

gens within a certain time period may be limited by the leukocyte population size. As a consequence hereof vaccination of very young fry may exhaust the leukocyte pool, and thereby leave vaccinates more vulnerable to secondary infections. However, this notion needs further elucidation.

\title{
5. Conclusion
}

The results provide insights to the occurrence of different leukocyte cells in blood and central immune organs (head kidney and spleen) at different size stages of rainbow trout with an exponential increase of immune cells with fish size. The results showed that lymphocytes dominated in blood, head kidney and spleen when compared to other leukocytes. It is well known that fish possesses immunological memory even in fry. This is the basis for a widely applied vaccination strategy in aquaculture enterprises but the capacity of fry to handle several pathogens at the same time may be limited. Therefore, further studies should not only shed light on characterization, localization and function of memory-B and memory- $\mathrm{T}$ cells in different size classes of fish, but also focus on the capacity of a certain leukocyte pool to respond to several antigens.

\section{Acknowledgements}

We are grateful to aquaculture assistants John Haakonsson and Claus Jespersen at the Bornholm Salmon Hatchery/Denmark for rearing fish for the project.

\section{References}

[1] Heinecke, R.D., Chettri, J.K. and Buchmann, K. (2014) Adaptive and Innate Immune Molecules in Developing Rain- 
bow Trout, Oncorhynchus mykiss Eggs and Larvae: Expression of Genes and Occurrence of Effector Molecules. Fish and Shellfish Immunology, 38, 25-33. http://dx.doi.org/10.1016/j.fsi.2014.02.010

[2] Chettri, J.K., Raida, M.K., Kania, P.W. and Buchmann, K. (2012) Differential Immune Response of Rainbow Trout (Oncorhynchus mykiss) at Early Developmental Stages (Larvae and Fry) against the Bacterial Pathogen Yersinia ruckeri. Developmental and Comparative Immunology, 36, 463-474. http://dx.doi.org/10.1016/j.dci.2011.08.014

[3] Fischer, U., Dijkstra, J.M., Kollner, B., Kiryu, I., Koppang, E.O., Hordvik, I., et al. (2005) The Ontogeny of MHC Class I Expression in Rainbow Trout (Oncorhynchus mykiss). Fish and Shellfish Immunology, 18, 49-60. http://dx.doi.org/10.1016/j.fsi.2004.05.006

[4] Overgard, A.C., Fiksdal, I.U., Nerland, A.H. and Patel, S. (2011) Expression of T-Cell Markers during Atlantic Halibut (Hippoglossus hippoglossus L.) Ontogenesis. Developmental and Comparative Immunology, 35, 203-213. http://dx.doi.org/10.1016/j.dci.2010.09.009

[5] Tatner, M.F. (1986) The Ontogeny of Humoral Immunity in Rainbow-Trout, Salmo-Gairdneri. Veterinary Immunology and Immunopathology, 12, 93-105. http://dx.doi.org/10.1016/0165-2427(86)90114-5

[6] Tatner, M.F. and Manning, M.J. (1983) The Ontogeny of Cellular-Immunity in the Rainbow-Trout, Salmo-Gairdneri Richardson, in Relation to the Stage of Development of the Lymphoid Organs. Developmental and Comparative Immunology, 7, 69-75. http://dx.doi.org/10.1016/0145-305X(83)90056-3

[7] Zapata, A., Diez, B., Cejalvo, T., Frias, C.G. and Cortes, A. (2006) Ontogeny of the Immune System of Fish. Fish and Shellfish Immunology, 20, 126-136. http://dx.doi.org/10.1016/j.fsi.2004.09.005

[8] Chettri, J.K., Jaafar, R.M., Skov, J., Kania, P.W., Dalsgaard, I. and Buchmann, K. (2015) Booster Immersion Vaccination Using Diluted Yersinia ruckeri Bacterin Confers Protection against ERM in Rainbow Trout. Aquaculture, 440, 15. http://dx.doi.org/10.1016/j.aquaculture.2015.01.027

[9] Jaafar, R.M., Chettri, J.K., Dalsgaard, I., Al-Jubury, A., Kania, P.W., Skov, J. and Buchmann, K. (2015) Effects of Adjuvant Montanide (TM) ISA 763 A VG in Rainbow Trout Injection Vaccinated against Yersinia ruckeri. Fish and Shellfish Immunology, 47, 797-806. http://dx.doi.org/10.1016/j.fsi.2015.10.023

[10] LaFrentz, B.R., LaPatra, S.E., Jones, G.R. and Cain, K.D. (2003) Passive Immunization of Rainbow Trout, Oncorhynchus mykiss (Walbaum), against Flavobacterium psychrophilum, the Causative Agent of Bacterial Coldwater Disease and Rainbow Trout Fry Syndrome. Journal of Fish Diseases, 26, 377-384. http://dx.doi.org/10.1046/j.1365-2761.2003.00468.x

[11] Aoki, M., Kondo, M., Nakatsuka, Y., Kawai, K. and Oshima, S.I. (2007) Stationary Phase Culture Supernatant Containing Membrane Vesicles Induced Immunity to Rainbow Trout Oncorhynchus mykiss Fry Syndrome. Vaccine, 25, 561-569. http://dx.doi.org/10.1016/j.vaccine.2006.07.047

[12] Tort, L., Balasch, J.C. and Mackenzie, S. (2003) Fish Immune System. A Crossroads between Innate and Adaptive Responses. Immunology, 22, 277-286.

[13] Fischer, U., Koppang, E.O. and Nakanishi, T. (2013) Teleost T and NK Cell Immunity. Fish and Shellfish Immunology, 35, 197-206. http://dx.doi.org/10.1016/j.fsi.2013.04.018

[14] Scapigliati, G. (2013) Functional Aspects of Fish Lymphocytes. Developmental and Comparative Immunology, 41, 200-208. http://dx.doi.org/10.1016/j.dci.2013.05.012

[15] Razquin, B.E., Castillo, A., Lopezfierro, P., Alvarez, F., Zapata, A. and Villena, A.J. (1990) Ontogeny of Igm-Producing Cells in the Lymphoid Organs of Rainbow-Trout, Salmo-Gairdneri Richardson-An Immunohistochemical and Enzyme-Histochemical Study. Journal of Fish Biology, 36, 159-173. http://dx.doi.org/10.1111/j.1095-8649.1990.tb05592.x

[16] Castillo, A., Sanchez, C., Dominguez, J., Kaattari, S.L. and Villena, A.J. (1993) Ontogeny of Igm and Igm-Bearing Cells in Rainbow-Trout. Developmental and Comparative Immunology, 17, 419-424. http://dx.doi.org/10.1016/0145-305X(93)90033-M

[17] Chettri, J.K., Raida, M.K., Holten-Andersen, L., Kania, P.W. and Buchmann, K. (2011) PAMP Induced Expression of Immune Relevant Genes in Head Kidney Leukocytes of Rainbow Trout (Oncorhynchus mykiss). Developmental and Comparative Immunology, 35, 476-482. http://dx.doi.org/10.1016/j.dci.2010.12.001

[18] Chettri, J.K., Holten-Andersen, L. and Buchmann, K. (2010) Factors Influencing in Vitro Respiratory Burst Assays with Head Kidney Leucocytes from Rainbow Trout, Oncorhynchus mykiss (Walbaum). Journal of Fish Diseases, 33, 593-602. http://dx.doi.org/10.1111/j.1365-2761.2010.01160.x

[19] Xueqin, J., Kania, P.W. and Buchmann, K. (2012) Comparative Effects of Four Feed Types on White Spot Disease Susceptibility and Skin Immune Parameters in Rainbow Trout, Oncorhynchus mykiss (Walbaum). Journal of Fish Diseases, 35, 127-135. http://dx.doi.org/10.1111/j.1365-2761.2011.01329.x

[20] Buchmann, K. (2007) An Introduction to Fish Parasitological Methods: Classical And Molecular Techniques. 
[21] Døving, K.R.E. (1992) Fiskens Fysiologi.

[22] Pettersen, E.F., Bjerknes, R. and Wergeland, H.I. (2000) Studies of Atlantic Salmon (Salmo salar L.) Blood, Spleen and Head Kidney Leucocytes Using Specific Monoclonal Antibodies, Immunohistochemistry and Flow Cytometry. Fish and Shellfish Immunology, 10, 695-710. http://dx.doi.org/10.1006/fsim.2000.0284

[23] Press, C.M., Dannevig, B.H. and Landsverk, T. (1994) Immune and Enzyme-Histochemical Phenotypes of Lymphoid and Nonlymphoid Cells within the Spleen and Head Kidney of Atlantic Salmon (Salmo-Salar L). Fish and Shellfish Immunology, 4, 79-93. http://dx.doi.org/10.1006/fsim.1994.1007

[24] Deshmukh, S., Kania, P.W., Chettri, J.K., Skov, J., Bojesen, A.M., Dalsgaard, I. and Buchmann, K. (2013) Insight from Molecular, Pathological, and Immunohistochemical Studies on Cellular and Humoral Mechanisms Responsible for Vaccine-Induced Protection of Rainbow Trout against Yersinia ruckeri. Clinical and Vaccine Immunology, 20, 1623-1641. http://dx.doi.org/10.1128/CVI.00404-13

[25] Wardle, C.S. (1971) New Observations on Lymph System of Plaice Pleuronectes Platessa and Other Teleosts. Journal of the Marine Biological Association of the United Kingdom, 51, 977-990. http://dx.doi.org/10.1017/S0025315400018099

[26] Rasmussen, K.J., Steffensen, J.F. and Buchmann, K. (2013) Differential Occurrence of Immune Cells in the Primary and Secondary Vascular Systems in Rainbow Trout, Oncorhynchus mykiss (Walbaum). Journal of Fish Diseases, 36, 675-679. http://dx.doi.org/10.1111/jfd.12058

[27] McMillan, D.N. and Secombes, C.J. (1997) Isolation of Rainbow Trout (Oncorhynchus mykiss) Intestinal Intraepithelial Lymphocytes (IEL) and Measurement of Their Cytotoxic Activity. Fish and Shellfish Immunology, 7, 527-541. http://dx.doi.org/10.1006/fsim.1997.0099

[28] Koppang, E.O., Fischer, U., Moore, L., Tranulis, M.A., Dijkstra, J.M., Köllner, B., Aune, L., Jirillo, E. and Hordvik, I. (2010) Salmonid T Cells Assemble in the Thymus, Spleen and in Novel Interbranchial Lymphoid Tissue. Journal of Anatomy, 217, 728-739. http://dx.doi.org/10.1111/j.1469-7580.2010.01305.x

[29] Olsen, M.M., Kania, P.W., Heinecke, R.D., Skjoedt, K., Rasmussen, K.J. and Buchmann, K. (2011) Cellular and Humoral Factors Involved in the Response of Rainbow Trout Gills to Ichthyophthirius multifiliis Infections: Molecular and Immunohistochemical Studies. Fish and Shellfish Immunology, 30, 859-869. http://dx.doi.org/10.1016/j.fsi.2011.01.010

[30] Chettri, J.K., Kuhn, J.A., Jaafar, R.M., Kania, P.W., Moller, O.S. and Buchmann, K. (2014) Epidermal Response of Rainbow Trout to Ichthyobodo necator: Immunohistochemical and Gene Expression Studies Indicate a Th1-/Th2-Like Switch. Journal of Fish Diseases, 37, 771-783. http://dx.doi.org/10.1111/jfd.12169

[31] Chettri, J.K., Deshmukh, S., Holten-Andersen, L., Jafaar, R.M., Dalsgaard, I. and Buchmann, K. (2013) Comparative Evaluation of Administration Methods for a Vaccine Protecting Rainbow Trout against Yersinia ruckeri O1 Biotype 2 Infections. Veterinary Immunologyand Immunopathology, 154, 42-47. http://dx.doi.org/10.1016/j.vetimm.2013.04.001

[32] Chettri, J.K., Skov, J., Jaafar, R.M., Krossøy, B., Kania, W.P., Dalsgaard, I. and Buchmann, K. (2015) Comparative Evaluation of Infection Methods and Environmental Factors on Challenge Success: Aeromonas salmonicida Infection in Vaccinated Rainbow Trout. Fish and Shellfish Immunology, 44, 485-495. http://dx.doi.org/10.1016/i.fsi.2015.03.003

[33] Rauta, P.R., Nayak, B. and Das, S. (2012) Immune System and Immune Responses in Fish and Their Role in Comparative Immunity Study: A Model for Higher Organisms. Immunology Letters, 148, 23-33. http://dx.doi.org/10.1016/j.imlet.2012.08.003

[34] Laing, K.J. and Hansen, J.D. (2011) Fish T Cells: Recent Advances through Genomics. Developmentaland Comparative Immunology, 35, 1282-1295. http://dx.doi.org/10.1016/j.dci.2011.03.004 


\section{Appendix}

Supplementary Table 1. Mean number with standard error (SEM) and mean percentages of different leukocyte cells (macrophage, neutrophil, and lymphocyte like-cells) from blood, head kidney, and spleen determined by light microscopy after gradient centrifugation on Percoll. Mean number represent 5 rainbow trout per group. Mean percentage in relation to all three types of cells.

\begin{tabular}{|c|c|c|c|c|c|c|}
\hline \multirow{2}{*}{$\begin{array}{c}\text { Groups } \\
\text { I: } \mathbf{2}-\mathbf{4} \mathbf{g}\end{array}$} & \multicolumn{2}{|c|}{ Macrophages } & \multicolumn{2}{|c|}{ Neutrophils } & \multicolumn{2}{|c|}{ Lymphocytes } \\
\hline & Mean \pm SEM & $\%$ & Mean \pm SEM & $\%$ & Mean \pm SEM & $\%$ \\
\hline Blood & $1 \times 10^{2} \pm 1 \times 10^{2}$ & $3 \%$ & $6 \times 10^{2} \pm 1 \times 10^{2}$ & $15 \%$ & $3 \times 10^{3} \pm 5 \times 10^{2}$ & $82 \%$ \\
\hline Head kidney & $1 \times 10^{3} \pm 6 \times 10^{2}$ & $7 \%$ & $3 \times 10^{3} \pm 2 \times 10^{3}$ & $11 \%$ & $1 \times 10^{4} \pm 6 \times 10^{3}$ & $82 \%$ \\
\hline Spleen & $5 \times 10^{1} \pm 5 \times 10^{1}$ & $1 \%$ & $2 \times 10^{1} \pm 2 \times 10^{1}$ & $1 \%$ & $4 \times 10^{3} \pm 1 \times 10^{3}$ & $98 \%$ \\
\hline \multicolumn{7}{|l|}{ II: 4 - $6 \mathrm{~g}$} \\
\hline Blood & $4 \times 10^{2} \pm 3 \times 10^{2}$ & $3 \%$ & $5 \times 10^{2} \pm 3 \times 10^{2}$ & $4 \%$ & $8 \times 10^{3} \pm 3 \times 10^{3}$ & $93 \%$ \\
\hline Head kidney & $3 \times 10^{2} \pm 1 \times 10^{3}$ & $1 \%$ & $2 \times 10^{3} \pm 2 \times 10^{3}$ & $2 \%$ & $8 \times 10^{4} \pm 1 \times 10^{4}$ & $97 \%$ \\
\hline Spleen & $3 \times 10^{2} \pm 2 \times 10^{2}$ & $1 \%$ & $2 \times 10^{2} \pm 2 \times 10^{2}$ & $1 \%$ & $3 \times 10^{4} \pm 6 \times 10^{3}$ & $98 \%$ \\
\hline \multicolumn{7}{|l|}{ III: 25 - $30 \mathrm{~g}$} \\
\hline Blood & 0 & $0 \%$ & $6 \times 10^{2} \pm 6 \times 10^{2}$ & $0 \%$ & $1 \times 10^{5} \pm 1 \times 10^{4}$ & $100 \%$ \\
\hline Head kidney & $4 \times 10^{3} \pm 2 \times 10^{3}$ & $1 \%$ & $1 \times 10^{3} \pm 1 \times 10^{3}$ & $0 \%$ & $5 \times 10^{5} \pm 1 \times 10^{5}$ & $99 \%$ \\
\hline Spleen & $8 \times 10^{2} \pm 8 \times 10^{2}$ & $0 \%$ & $7 \times 10^{2} \pm 4 \times 10^{2}$ & $0 \%$ & $2 \times 10^{5} \pm 6 \times 10^{4}$ & $99 \%$ \\
\hline \multicolumn{7}{|l|}{ IV:650 - $780 \mathrm{~g}$} \\
\hline Blood & $2 \times 10^{4} \pm 9 \times 10^{3}$ & $3 \%$ & $3 \times 10^{4} \pm 1 \times 10^{4}$ & $5 \%$ & $8 \times 10^{5} \pm 2 \times 10^{5}$ & $93 \%$ \\
\hline Head kidney & $6 \times 10^{5} \pm 3 \times 10^{5}$ & $9 \%$ & $5 \times 10^{5} \pm 2 \times 10^{5}$ & $6 \%$ & $6 \times 10^{6} \pm 2 \times 10^{6}$ & $85 \%$ \\
\hline Spleen & $2 \times 10^{4} \pm 2 \times 10^{4}$ & $1 \%$ & $2 \times 10^{4} \pm 2 \times 10^{4}$ & $1 \%$ & $2 \times 10^{6} \pm 6 \times 10^{5}$ & $98 \%$ \\
\hline
\end{tabular}

Supplementary Table 2. Comparative and quantitative data analysis of each leukocyte population isolated from blood, head kidney and spleen. Student's $t$-test and one way ANOVA with Tukey's post hoc test for parametric data were used. For nonparametric data Mann-Whitney $U$ test and Kruskal-Wallis one-way ANOVA were performed with the Dunn multiple-comparison test were applied. Head kidney (HK), Spleen (SP), Blood (BL), Before Percoll (BP), After Percoll (AP).

\begin{tabular}{|c|c|c|c|c|c|c|}
\hline \multirow{2}{*}{$\begin{array}{l}\text { Group I: } 2 \text { - } 4 \text { g } \\
\text { Statistical test }\end{array}$} & \multicolumn{2}{|c|}{ Macrophages } & \multicolumn{2}{|c|}{ Neutrophils } & \multicolumn{2}{|c|}{ Lymphocytes } \\
\hline & $\begin{array}{l}\text { HKBP } \\
\text { vsSPBP }\end{array}$ & $\begin{array}{l}\text { BLAPvs HKAPvs } \\
\text { SPAP }\end{array}$ & $\begin{array}{l}\text { HKBPvs } \\
\text { SPBP }\end{array}$ & $\begin{array}{l}\text { BLAPvs HKAPvs } \\
\text { SPAP }\end{array}$ & $\begin{array}{l}\text { HKBPvs } \\
\text { SPBP }\end{array}$ & $\begin{array}{l}\text { BLAPvs HKAPvs } \\
\text { SPAP }\end{array}$ \\
\hline student $t$-test & \multirow{4}{*}{0.10} & \multirow[b]{4}{*}{0.01} & \multicolumn{2}{|l|}{0.06} & \multirow{4}{*}{0.01} & \multirow{4}{*}{0.09} \\
\hline Mann-Whitney $U$ Test & & & & & & \\
\hline $\begin{array}{l}\text { One-way ANOVA with } \\
\text { Tukey's post hoc test }\end{array}$ & & & & & & \\
\hline $\begin{array}{l}\text { KrusKal-Wallis one-way } \\
\text { ANOVA test }\end{array}$ & & & & 0.01 & & \\
\hline Group II: 4 - $6 \mathrm{~g}$ & \multicolumn{2}{|c|}{ Macrophages } & \multicolumn{2}{|c|}{ Neutrophils } & \multicolumn{2}{|c|}{ Lymphocytes } \\
\hline Statistical test & $\begin{array}{l}\text { HKBP } \\
\text { vsSPBP }\end{array}$ & $\begin{array}{l}\text { BLAPvs HKAPvs } \\
\text { SPAP }\end{array}$ & $\begin{array}{l}\text { HKBPvs } \\
\text { SPBP }\end{array}$ & $\begin{array}{l}\text { BLAPvs HKAPvs } \\
\text { SPAP }\end{array}$ & $\begin{array}{l}\text { HKBPvs } \\
\text { SPBP }\end{array}$ & $\begin{array}{l}\text { BLAPvs HKAPvs } \\
\text { SPAP }\end{array}$ \\
\hline student $t$-test & & & No-data & & & \\
\hline Mann-Whitney $U$ Test & 0.4 & & & & 0.01 & \\
\hline
\end{tabular}




\section{Continued}

One-way ANOVA with

Tukey's post hoc test

KrusKal-Wallis one-way ANOVA test

Group III: 25 - 30 g

Statistical test

student $t$-test

Mann-Whitney $U$ Test

One-way ANOVA with

Tukey's post hoc test

KrusKal-Wallis one-way

ANOVA test

Group IV: 650 - 780 g

Statistical test

student $t$-test

Mann-Whitney $U$ Test

One-way ANOVA with

Tukey's post hoc test

KrusKal-Wallis one-way ANOVA test
0.8

0.9

0.01
Macrophages

HKBP
vSSPBP

BLAPvs HKAPvs SPAP

0.2

Macrophages

HKBP vSSPBP

BLAPvs HKAPvs SPAP

0.01

0.01
Neutrophils

HKBPvs SPBP

BLAPvs HKAPvs SPAP

No data
Lymphocytes

HKBPys BLAPvs HKAPvs SPBP SPAP

0.01
0.9

Neutrophils

HKBPVs SPBP

BLAPvs HKAPvs SPAP

0.01
Lymphocytes

HKBPvs BLAPvs HKAPvs SPBP SPAP
0.01

\section{Submit or recommend next manuscript to SCIRP and we will provide best service for you:}

Accepting pre-submission inquiries through Email, Facebook, LinkedIn, Twitter, etc.

A wide selection of journals (inclusive of 9 subjects, more than 200 journals)

Providing 24-hour high-quality service

User-friendly online submission system

Fair and swift peer-review system

Efficient typesetting and proofreading procedure

Display of the result of downloads and visits, as well as the number of cited articles

Maximum dissemination of your research work

Submit your manuscript at: http://papersubmission.scirp.org/ 